Annals of Warsaw University of Life Sciences - SGGW

Land Reclamation No 42 (2), 2010: 241-247

(Ann. Warsaw Univ. of Life Sci. - SGGW, Land Reclam. 42 (2), 2010)

\title{
The effect of plant cover on the mechanical composition of eroded soil
}

\author{
ANNA BARYŁA ${ }^{1}$, LESZEK HEJDUK $^{2}$ \\ ${ }^{1}$ Department of Environmental Improvement, Warsaw University of Life Sciences - SGGW \\ ${ }^{2}$ Department Hydraulic Engineering and Environmental Restoration, Warsaw University of Life \\ Sciences - SGGW
}

\begin{abstract}
The effect of plant cover on the mechanical composition of eroded soil. Water erosion causes migration of the finest soil particles and chemical compounds. The paper attempts to compare the mechanical composition of sediments susceptible to water erosion on the hillslopes with different cover crops. The research was conducted on the experimental plots in Puczniew. Its results showed that the composition of the sediment washed out from the fallow land significantly differed from that washed out from the plots with grass and barley crops. In the case of fallow land, soil particles were markedly larger. This might indicate the existence of a very hard mineral fraction.
\end{abstract}

Key words: water erosion, grain size distribution, sediment.

\section{INTRODUCTION}

Soil degradation due to, inter alia, water erosion causes significant physical damage and economic losses, as well as deterioration of the natural environment, thus reducing the agricultural development potential. A change in the use of land covered by natural vegetation, like forest or steppe, into arable fields automatically causes increased erosion on the hillslopes.

Erosion intensity depends on vegetation cover selection. Field crops provide some protection, however, the seasonal- ity of vegetation cover, mechanical cultivation and tending, intervals between crop rotations create conditions for the development of erosion processes. Due to the lack of vegetation cover in the periods of snowmelt and summer torrential rainfalls, arable land is particularly vulnerable to water erosion. The soil loss results in a loss of soil fertility and reduces the economic effectiveness of agricultural production (Rejman 2006). Fertilizer components and plant protection agents leached from the soil increase surface water pollution. The soil particles carried out with sediments to ditches, water bodies and hydrological facilities deteriorate their functioning and shorten the period of their technological usefulness. Water erosion causes the migration of ultrafine soil particles and elements, which is reflected in the granulometric composition of soils and their chemical properties.

The aim set by the authors of this paper was to analyze the differences in the mechanical composition of the sediment washed out from the plots with different cover crops. In the studies on soil erosion, much attention was given to the glanulometric composition of the eroded sediments (Govers 1985; Slattery and Burt 1997; Beuselinck et al. 2000). Deposited after heavy rains were analysed 
or subjected to rainfall simulation. The paper presents the results of the exemplary results of the studies on the granulometric composition of eroded soils from the plots on the slopes covered with grass and barley. The plot with black fallow was established as control.

\section{MATERIALS AND METHODS}

The research station was established in the Agricultural Experimental Station in Puczniew. The arable land in the Puczniew RZD is underlain by Quaternary soils formed by the action of glaciers, mostly composed of boulder clays of the older glaciation ground moraine and glacier accumulation sands with rocks on boulder clay.

The mechanical composition of soils showed that loamy soils, poorly resistant to erosion processes, occurred all along the slope length (Józefaciuk A. and Józefaciuk C. 1996). In the top area of the slope, the soil surface is less permeable, as evidenced by the permeability coefficient $-0.01 \mathrm{~m} \cdot \mathrm{d}^{-1}$. In the bottom area, the soil surface is characterized by a greater and more variable permeability (permeability coefficient was $\left.0.8-10 \mathrm{~m} \cdot \mathrm{d}^{-1}\right)$. The bulk density of soil for a layer of 10-15 $\mathrm{cm}$ is $1.60 \mathrm{~g} \mathrm{~cm}^{-3}$. The studies were conducted on three $4 \mathrm{~m}$ wide and $40 \mathrm{~m}$ long plots, with an average slope gradient of $10 \%$. Prior to the experiment established in 2006, the plots were tilled (shallow ploughing), then one plot was sown with grass, the second - with barley and the third plot was maintained as black fallow throughout the experiment. The sediment washed out during the rainfall was taken from the tanks placed at the end of each plot and subjected to analysis. A Mastersizer Microplus of the Malvern Instruments Ltd. was used for grain size distribution analyses (Rawle 1997). The technique applied in this device is compatible with the ISO13320 standard - The International Standard For Laser Diffraction Measurements.

According to Adamiak (2001), the results obtained by the applied laser diffraction technique are different to those obtained by the previously used sedimentation methods. This is dictated by the fact that the laser diffraction technique is based on different laws of physics and applies different approximations compared to the sedimentation method. In comparison with traditional methods, the laser marking technique slightly underestimates the clay $(<4 \mathrm{mi}-$ crons) and sand (>63 microns) content and overestimates the silt content (4-63 microns) (Beuselinck et al. 1998; Mason et al. 2003 for Jary 2007). Nonetheless, many authors (Banasik and Hejduk 2005; Szewrański 2009) believe that this method has many advantages. Among the most important are the speed of analysis, small sample weight $(0.3 \mathrm{~g})$, high measurement accuracy, repeatability of results, the possibility to analyze grain sizes up to 100 classes, automatic laser marking. In order to break up soil aggregates, the collected samples were treated with ultrasound waves, and microscopic images were taken.

\section{RESULTS AND DISCUSSION}

The studies showed (Fig. 1) that in the case of black fallow, the average sand content was $72 \%$, silt content $-23 \%$ and clay content $-5 \%$. For the plot with the 


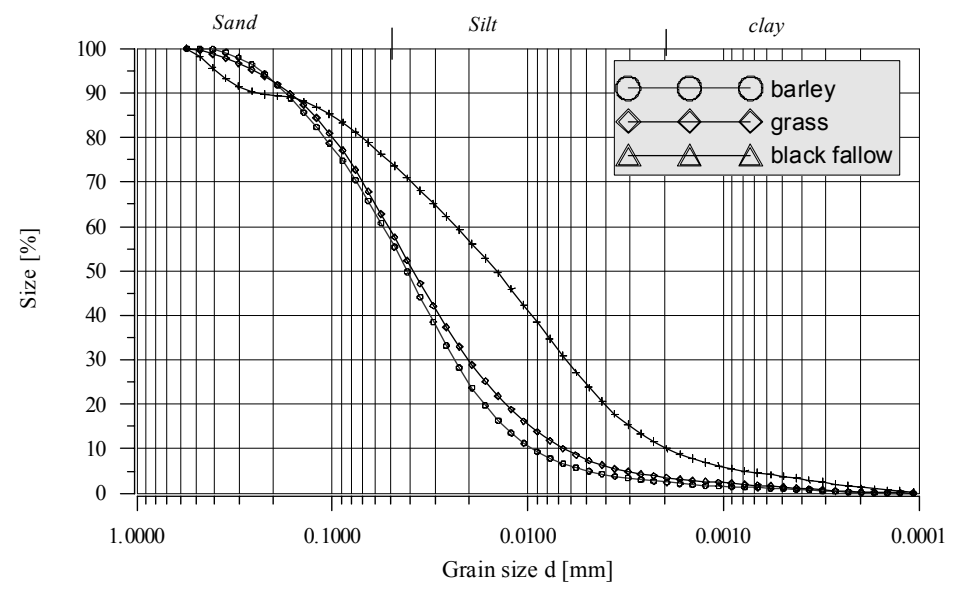

FIGURE 1. Sediment grain size

grass cover, the sand content was $91 \%$, silt content $-7 \%$, clay content $-2 \%$. For the plot with barley, the sand content was $93 \%$, silt content $-5 \%$ and the clay content $-2 \%$.

The obtained data showed that the smallest sand content was for black fallow $(20 \%$ on average), whereas in the case of barley and grass the sand content was at a similar level accounting for $91 \%$ and $93 \%$, respectively. The silt content was highest for the fallow land. In all cases, the sand content had the largest share in the analyzed sediments.

The studies by Smolska (2008) using traditional methods demonstrated that in the case of black fallow, the content of silt and clay were larger in the bottom area of the slope indicating the transport of smaller particles, with the larger ones being left on the slope.

The use of the laser diffraction method allowed precise definition of effective diameter sizes $\mathrm{d} 10, \mathrm{~d} 50$ and $\mathrm{d} 90$. The value of the $\mathrm{d} 10$ diameter amounted to $2 \mu \mathrm{m}$ for black fallow, 5.5 microns for grass and $9.5 \mu \mathrm{m}$ for barley. The value of the D50 diameter was $15 \mu \mathrm{m}$ for fallow,
$39 \mu \mathrm{m}$ for grass and $42 \mu \mathrm{m}$ for barley. The uniformity coefficient $U=d 60 / d 10$ calculated for the analysed distributions attained the value of $12.5 \mu \mathrm{m}$ for grass, $8.7 \mu \mathrm{m}$ for fallow and $6.5 \mu \mathrm{m}$ for barley.

The obtained results also enabled to determine the vulnerability of a soil to soil loss. Two factors influence this characteristic: soil compaction and soil aggregate stability. The smaller is soil compaction and aggregate stability, its erosivity is greater.

According to Prochal (1984) this relationship can be characterized as the ratio of silt fractions $(0.1-0.02 \mathrm{~mm})$ to colloidal fraction $(0.002 \mathrm{~mm})$. For surface runoffs, sand particles with a small aggregate surface area are rarely carried away by water. However, particles with larger aggregate surface area (silts) are transported even when water velocity is $0.02-0.05 \mathrm{~m} / \mathrm{s}$.

During runoff, the eroded particles (with a diameter of less than $0.02 \mathrm{~mm}$ ) increase their adhesive properties with the increasing aggregate surface area. It means that soils with the prevalence of silt fractions with a small colloidal frac- 
tion are most vulnerable to soil loss. As regards clay loamy soils in Puczniew, the ratio of the silt fraction to the colloidal fraction for the topsoil amounted to 3.3 for medium clay in which the content of silt was $10.7 \%$ of weight and of eroded fractions $-35 \%$ of weight.

Figures 2-4 illustrate the selected sediment density distributions for individual land uses.

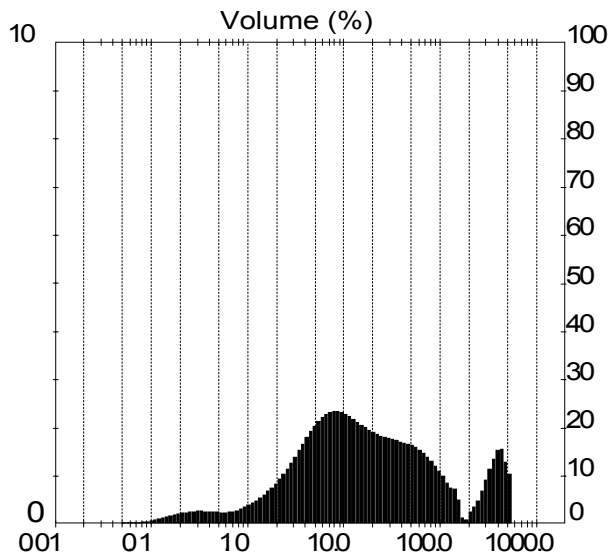

Particle Diameter ( $\mu \mathrm{m})$

FIGURE 2. Selected sediment density distributions - black fallow

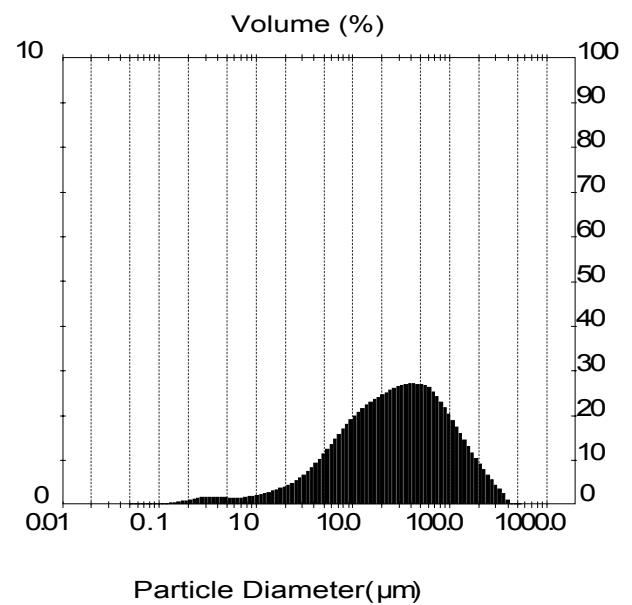

FIGURE 3. Selected sediment density distributions - grass

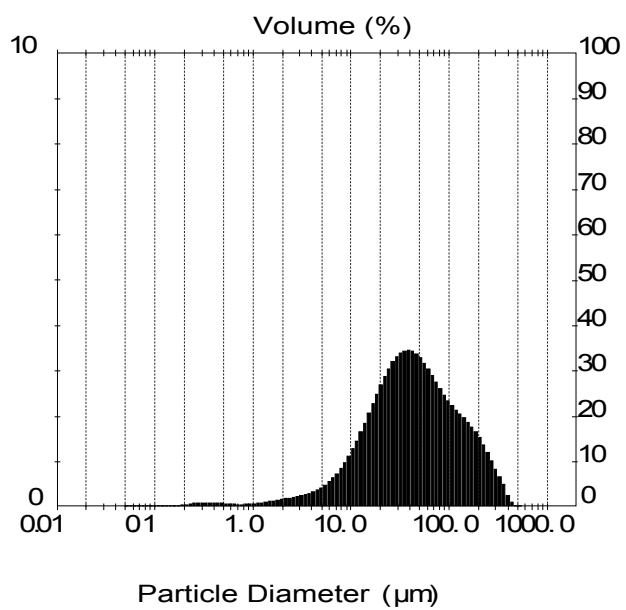

FIGURE 4. Selected sediment density distributions - barley

The obtained results of the sediment density distribution (Figs. 2-4) for individual land uses allowed to state that in the case of the sand content, the particles in the black fallow sediment were much larger than in the sediment washed from the plots with barley and grass cover, which was confirmed by the additional peak for the largest particles. The peak was noted even after breaking up the soil samples by ultrasound waves. This might indicate a very hard mineral fraction. The microscopic analyses of sediments from three plots with different land uses were compared with sediments after their breaking up by ultrasound waves. The obtained results are presented in Photos 1-3.

The analysis of microscopic images showed that after the break up by ultrasound waves, the tested sediment did not change significantly, which might indicate that the content of organic material was low. 

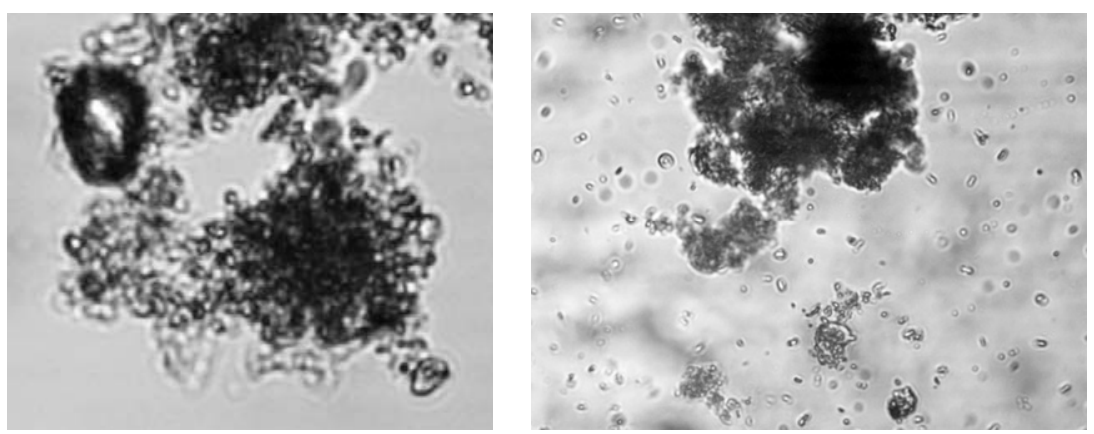

FOT. 1. The microscopic analyses of sediments from black fallow plot with sediments after their breaking up by ultrasound waves
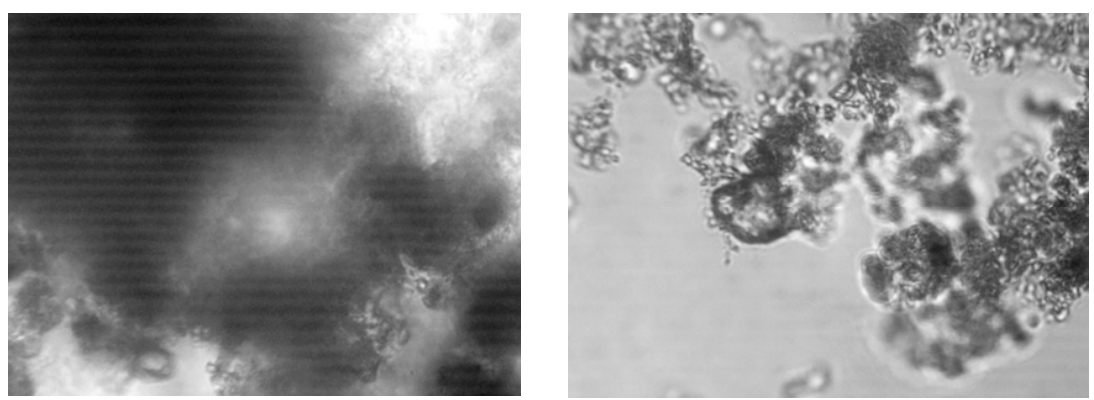

FOT. 2. The microscopic analyses of sediments from grass plot with sediments after their breaking up by ultrasound waves
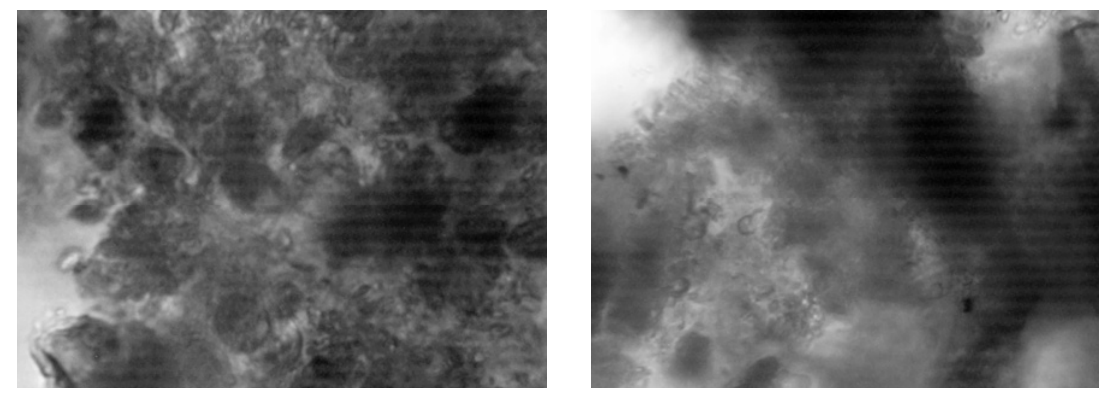

FOT. 3. The microscopic analyses of sediments from barley plot with sediments after their breaking up by ultrasound waves

\section{CONCLUSIONS}

The analyses of the sediment composition transported from 3 plots showed differences which might be important for the agricultural use of land.
The comparison of the results of grain size analysis using the laser diffraction method with other techniques, like aerometric creates certain difficulties (Banasik and Hejduk 2005). The studies on loess soils (Dębicki et al. 2002) 
showed that their granulometric composition was different when using the laser method and aerometric methods. Some authors emphasize the need to seek correlations between the results obtained by the above-mentioned methods for each tested sample (Bauselinck et al. 1998, Frankowski and Smagała 2000).

The obtained results allowed to formulate the following conclusions:

1. As regards clay loamy soil clear differences were found in the granulometric composition of the sediment carried from the plots with a different crop cover.

2. The studies showed that the sediment washed out from black fallow significantly differed from the composition of the sediment washed out from the plots with grass and barley. Large differences were noted for the sand content $-20 \%$, silt content $-14 \%$, clay content $-6 \%$.

3 . As regards the fallow plot, the particles were significantly larger compared to those of barley and grass plots (which might indicate a very hard mineral fraction and the absence of unstable aggregates).

\section{REFERENCES}

ADAMIAK W. 2001: Analiza porównawcza różnych metod badania uziarnienia gruntów. (Comparison analysis of different methods of soil particles testing) Warszawa, Praca magisterska. MSc thesis SGGW.

BANASIK K., HEJDUK L. 2005: Badania granulometrii rumowiska unoszonego w małej rzece nizinnej. (Grain size distribution of suspended sediment in small lowland river) Acta Agrofizyka 5(2), 253-262 [Engl. summ.].
BEUSELINCK L., STEEGEN A., GOVERS G., NATCHERGAELE J., TAKKEN I., POESON J. 2000: Characteristics of sediment deposits formed by intense rainfall events in small catchments in the Belgian Loam Belt. Geomorphology. 32: 69-82.

BEUSELINCK L., GOVERS G., POESEN J., DEGRAER G., FROYEN L. 1998: Grain-size analysis by laser diffractometry: comparision with the sieve-pipette method. Catena. 32, 193-208.

DĘBICKI R., KLIMOWICZ Z., ZAGŁOBICKI W. 2002: Porównanie rozkładu granulometrycznego oznaczonego metodą areometryczną i laserową na przykładzie gleb lessowych (Comparison of grain size distribution tested by aerometric and laser metod - lessy soils case study). Acta Agrophysica, 56, 95-104 (Engl. summ.).

FRANKOWSKI Z., SMAGAŁA S. 2000: Przydatnosć metody laserowej w badaniach uziarnienia gruntów spoistych. (Usefulness of laser particle size in the cohesive soil). XII krajowa konferencja mechaniki gruntów i fundamentowania. „Problemy geotechniczne obszarów przymorskich". mat. konf. 163-171.

GOVERS G. 1985: Selectivity and transport capacity of thin flows in relation to rill erosion. Catena 12: 35-49.

JARY Z., BOGUCKYJ A., CISEK D., KIDA J. 2007: Zmiany klimatu zapisane w górnoplejstoceńskich sekwencji lessowoglebowych zachodniej części Ukrainy. (Climate change is recorded in the loess sequence gornoplejstoceńskich soil-western part of Ukraine). Annales Universitatis Mariae Curie-Sklodowska. Lublin - Polonia, vol. LXII/8: 189-210 [Engl. summ.].

JÓZEFACIUK A., JÓZEFACIUK Cz. 1996: Mechanizm i wskazówki metodyczne badania procesów erozji. [Mechanism and methodological suggestions for investigation erosion processes]. PIOŚ, Biblioteka Monitoringu Środowiska w Warszawie (Engl. summ.).

PROCHAL P. 1984: Melioracje przeciwerozyjne. (Soil erosion contro) Wykłady. 
Kraków, Akademia Rolnicza w Krakowie.

REJMAN J. 2006: Wpływ erozji wodnej i uprawowej na przekształcenie gleb i stoków lessowych. (Effect of water and tillage erosion on transformation of soils and loess slopes) Acta Agrophysica, 136, s. 50-70 [Engl. summ.].

RAWLE A. 1997: The basic principles of particle size analysis. Malvern Instruments Ltd., Malvern, Wielka Brytania.

SMOLSKA E. 2008: Badania sedymentologiczne współczesnych osadów deluwialnych i ich znaczenie w ocenie dynamiki procesów erozji gleby na przykładzie Pojezierza Suwalskiego. (Assesment of soil erosion processes based on sedimentological analyses of contemporary deluvial sediments on the example of the Suwałki Lakeland). Prz. Nauk. Inż. Kszt. Środ $S G G W, 40:$ 202-212 [Engl. summ.].

SLATTERY M.C., BURT T.P. 1997: Particle size characteristics of suspended sediment in hillslope runoff and stream flow. Earth Surf. Process. Landforms 22: 705-719.

SZEWRAŃSKI Sz. 2009: Rozbryzg jako forma erozji wodnej gleb lessowych. (Raindrop splash as the form of loess soils erosion) Wyd. Uniw. Przyrod. Wrocław. Mon. LXXVIII. p. 89-92 [Engl. summ.].

\section{Acknowledgements}

Presented work was carried within work Grant programe (2P06S02229) founded by Polish Ministry of Scientific Research and Information Technology.

Streszczenie: Wplyw pokrywy roślinnej na skład mechaniczny erodowanej gleby. W wyniku erozji wodnej następuje migracja najdrobniejszych cząstek glebowych oraz związków chemicznych. W artykule podjęto próbę porównania składu mechanicznego osadów ulegających erozji wodnej na stokach różnie użytkowanych na podstawie badań prowadzonych na poletkach doświadczalnych w Puczniewie. Z przeprowadzonych badań wynika, że wymywany sedyment $\mathrm{z}$ ugoru znacznie różni się od składu sedymentu wymywanego z poletek użytkowanych jako trawa i jęczmień. W przypadku ugoru pojawiły się dużo większe cząsteczki niż w przypadku jęczmienia i trawy, świadczy o tym dodatkowy pik przy cząstkach największych. Może to świadczyć o tym, że jest to bardzo twarda frakcja mineralna.

Słowa kluczowe: skład mechaniczny sedymentu, zmywy powierzchniowe, erozja wodna.

MS. received November 15, 2010

\section{Authors' address:}

Anna Baryła

Katedra Kształtowania Środowiska

SGGW, ul. Nowoursynowska 166, 02-787

Warszawa

e-mail: anna_baryla@sggw.pl 